$\begin{array}{ll}\text { Abstracta Iranica } & \begin{array}{l}\text { Abstracta Iranica } \\ \text { Revue bibliographique pour le domaine irano-aryen }\end{array} \\ & \text { Volume } \mathbf{3 0} \mid \mathbf{2 0 1 0} \\ & \text { Comptes rendus des publications de } \mathbf{2 0 0 7}\end{array}$

\title{
Judah and the Judeans in the Persian Period. Winona Lake (Indiana), Eisenbrauns, 2006, 721 p.
}

\section{Astrid Nunn}

\section{(2) OpenEdition}

1 Journals

Édition électronique

URL : http://journals.openedition.org/abstractairanica/37663

DOI : 10.4000/abstractairanica.37663

ISSN : 1961-960X

Éditeur :

CNRS (UMR 7528 Mondes iraniens et indiens), Éditions de l'IFRI

\section{Édition imprimée}

Date de publication : 8 avril 2010

ISSN : 0240-8910

\section{Référence électronique}

Astrid Nunn, « Judah and the Judeans in the Persian Period. Winona Lake (Indiana), Eisenbrauns, 2006,

721 p. », Abstracta Iranica [En ligne], Volume 30 | 2010, document 83, mis en ligne le 08 avril 2010

consulté le 29 septembre 2020. URL : http://journals.openedition.org/abstractairanica/37663 ; DOI : https://doi.org/10.4000/abstractairanica.37663

Ce document a été généré automatiquement le 29 septembre 2020.

Tous droits réservés 


\title{
Judah and the Judeans in the Persian Period. Winona Lake (Indiana), Eisenbrauns, 2006, $721 \mathrm{p}$.
}

\author{
Astrid Nunn
}

Ce volume est le résultat d'un symposium sur la Judée qui eu lieu à Heidelberg en 2003. La première partie est plus centrée sur l'histoire, l'épigraphie et l'archéologie alors que la seconde - plus courte - l'est sur la Bible. Le retour de l'Exil, présenté comme évènement unique, est-il un mythe ou y a-t'il eu plusieurs retours à Jérusalem ? La vie des communautés rurales, les termes désignant les habitants de Judée, les frontières de la Judée, le tracé des murs de Jérusalem, les changements amenant à créer un centre administratif à Lachish (il s'agit de la couche I, achéménide plutôt qu'hellénistique), la baisse du nombre de sanctuaires et de terres cuites en Judée par rapport aux VIII et VII e siècles, les archives de Jedaniah de Jeb (Eléphantine), l'arrivée de Cyrus à Babylone, l'administration perse et l'onomastique judéenne à Babylone, les ostracas araméens de Khirbet el-Kôm/Makkedah, tels sont des thèmes très divers abordés dans ce volume qui un temps restera notre somme de savoir sur la Judée achéménide.

\section{INDEX}

Thèmes : 3.2.2. Pré-Achéménides et Achéménides 
AUTEURS

ASTRID NUNN

Université de Munich 